\title{
HUBUNGAN GANGGUAN MAKAN DAN KUALITAS DIET DENGAN STATUS ANEMIA PADA REMAJA PUTRI DI MODELLING SCHOOL
}

\author{
Francisca Natalia Bintang, Fillah Fithra Dieny*, Binar Panunggal \\ Departemen Ilmu Gizi, Fakultas Kedokteran, Universitas Diponegoro \\ Jl. Prof. Sudarto SH, Tembalang, Semarang, Jawa Tengah 50275, Indonesia \\ *Penulis Penanggungjawab. E-mail: fillahdieny@gmail.com
}

\begin{abstract}
Background: Adolescence who was fashion model had concern about weight gain leaned to restrict their food intake so that increased risk of eating disorder and anemia. This study aimed to analyze association between eating disorder and diet quality with anemia status in female adolescence at modelling school.

Method: Observational study with cross-sectional design involved 55 female adolescence aged 12-19 years chose by consecutive sampling and was done at Modelling School Semarang. Hemoglobin level was measured by Cyanmethemoglobin method, eating disorder was obtained by eating disorder diagnostic scale questionnaire and diet quality was obtained by food frequency questionnaire then score was calculated by diet quality index international form. Data analysis used Chi Square test.

Results: There was 25 subjects who had anemia (45.5\%). Eating disorder was found in 29 subjects (52.7\%) which 11 subjects had bulimia nervosa. Percentage of female adolescence (63.6\%) who had low diet quality was more than high diet quality (36.4\%). The results showed that subjects (41.4\%) who had anemia also had eating disorder $(p=0.243)$, and subjects (45.7\%) who had anemia also had low diet quality (p=0.959). Low diet quality (65.5\%) was found more in the eating disorder group $(p=0.866)$.

Conclusion: There were no association between eating disorder and diet quality with anemia status in female adolescence at modelling school $(p>0.05)$.
\end{abstract}

Keywords: eating disorder; diet quality; anemia; adolescence

\begin{abstract}
ABSTRAK
Latar belakang: Remaja yang berprofesi sebagai model sering merasa takut jika mengalami kenaikan berat badan memiliki kecenderungan membatasi asupan makan. Hal ini dapat meningkatkan risiko terjadinya gangguan makan dan anemia. Penelitian ini bertujuan menganalisis hubungan antara gangguan makan dan kualitas diet dengan status anemia pada remaja putri di Modelling School.

Metode: Penelitian observasional dengan desain cross-sectional melibatkan 55 remaja putri berumur 12-19 tahun yang dipilih secara consecutive sampling dan dilakukan di Sekolah Model Semarang. Kadar hemoglobin (Hb) diukur dengan metode Cyanmethemoglobin, gangguan makan menggunakan kuesioner Eating Disorder Diagnostic Scale (EDDS), dan kualitas diet diukur dengan formulir food frequency questionnaire (FFQ), kemudian dihitung skor kualitas dietnya menggunakan panduan Diet Quality Index International (DQI-I). Analisis data menggunakan uji Chi Square.

Hasil: Subjek yang mengalami anemia sebanyak 25 orang (45,5\%). Gangguan makan ditemukan pada 29 subjek (52,7\%) dengan 11 orang mengalami bulimia nervosa. Persentase remaja putri (63,6\%) yang memiliki kualitas diet rendah pada penelitian ini lebih banyak dibandingkan dengan remaja (36,4\%) yang memiliki kualitas diet tinggi. Hasil menunjukkan subjek $(41,4 \%)$ yang anemia juga mengalami gangguan makan $(p=0,243)$, dan subjek $(45,7 \%)$ yang anemia memiliki kualitas diet yang rendah $(p=0,959)$. Kualitas diet rendah $(65,5 \%)$ ditemukan lebih banyak pada kelompok yang mengalami gangguan makan ( $p=0,866)$.
\end{abstract}

Simpulan: Tidak ada hubungan antara gangguan makan dan kualitas diet dengan status anemia pada remaja putri di modelling school $(p>0,05)$

Kata kunci: gangguan makan; kualitas diet; anemia; remaja

\section{PENDAHULUAN}

Anemia didefinisikan sebagai suatu keadaan dimana jumlah sel darah merah dan komponen hemoglobin $(\mathrm{Hb})$ dalam darah jumlahnya kurang dari kadar normal akibat ketidakmampuan jaringan membentuk sel darah merah guna mempertahankan kadar hemoglobin pada tingkat normal. ${ }^{1}$ Menurut data WHO tahun 2011, secara global prevalensi anemia pada wanita usia reproduktif adalah $29,4 \%$ dan daerah Asia Tenggara memiliki konsentrasi ratarata hemoglobin terendah dan prevalensi tertinggi anemia, dengan jumlah anak-anak dan wanita dengan anemia terbanyak, yaitu 96,7 juta anak-anak dan 202 juta wanita pada usia reproduktif. ${ }^{2}$ Menurut laporan 
Riset Kesehatan Dasar tahun 2013, prevalensi anemia secara nasional adalah $21,7 \%$ dengan proporsi anemia pada perempuan lebih tinggi dibandingkan pada laki-laki yaitu sebesar 23,9\%. ${ }^{3}$ Menurut penelitian di Semarang tahun 2013, sebanyak 60 dari 84 remaja putri atau dengan prevalensi sebesar $71,4 \%$ mengalami anemia dan penelitian di Kabupaten Semarang pada tahun 2015 sebanyak 38 dari 70 orang atau $54,3 \%$ mengalami anemia. ${ }^{4,5}$

Beberapa faktor risiko terkait anemia pada remaja antara lain pertumbuhan, inadekuat asupan sumber zat besi atau vitamin $\mathrm{C}$, diet vegan, pembatasan kalori, melewatkan waktu makan (meal skipping) dan menstruasi. ${ }^{6}$ Perubahan kadar ferritin serum pada remaja putri selama masa reproduksi, disertai perkembangan fisiologis tubuh selama masa pubertas yang menyebabkan kebutuhan gizi meningkat. $^{7}$

Ketidakpuasan terhadap bentuk dan ukuran tubuh semakin sering dijumpai di kalangan remaja putri, khususnya di kalangan model. Fenomena ini disebabkan oleh lebih besarnya tekanan sosial untuk tampil langsing, sehingga ditemukan kecenderungan mengalami underweight. ${ }^{8}$ Sebuah penelitian pada remaja putri yang berprofesi sebagai model di Semarang menunjukkan bahwa asupan remaja yang berprofesi sebagai model belum baik dan sebagian memiliki status gizi yang kurang, dilihat dari sebanyak $80,6 \%$ remaja memiliki status gizi kurang. ${ }^{9}$ Hal itu memperkuat pernyataan bahwa populasi remaja yang berprofesi sebagai model merupakan salah satu populasi risiko tinggi mengalami masalah gizi karena kelompok model yang cenderung underweight memiliki keinginan kuat untuk menjadi lebih kurus dibandingkan dengan kelompok nonmodel. ${ }^{8,10}$

Tingginya kompetisi di dunia fashion dan tekanan untuk mendapatkan bentuk tubuh ideal membuat model menerapkan sejumlah metode untuk mengontrol berat badan, antara lain berdiet, pantang makan, latihan yang berlebih, memuntahkan makan atau menggunakan obat-obatan untuk mengurangi asupan kalori. Faktor-faktor tersebut dapat memicu terjadinya gangguan makan dan indeks massa tubuh yang rendah pada model. ${ }^{8}$ Ketakutan mengalami kenaikan berat badan dan kebiasaan makan yang kurang baik adalah penyebab utama kurangnya sumber asupan hewani yang dapat berdampak pada anemia. ${ }^{11}$ Indeks massa tubuh yang rendah juga menjadi indikator inadekuat asupan kalori dan juga merupakan determinan anemia pada remaja. ${ }^{12,13}$ Penelitian dilakukan di Modelling Agency Semarang pada tahun 2014 yang menunjukkan bahwa ada hubungan kejadian gangguan makan dengan status gizi pada remaja putri usia 15-19 tahun, dengan ditemukan $67,8 \%$ mengalami gangguan makan dengan $18,6 \%$ remaja yang termasuk kategori underfat. ${ }^{14}$

Gangguan makan yang terjadi dapat mengganggu kualitas diet pada remaja. Hal tersebut ditunjukkan pada penelitian Zimmerman pada tahun 2016 terhadap 27 remaja putri berumur 14-18 tahun yang mengalami gangguan makan, rata-rata asupan kalori adalah $1200 \mathrm{kkal}$ dengan persentase $36 \%$ dari lemak, $46 \%$ dari karbohidrat, dan $18 \%$ dari protein. Asupan mikronutrien juga sangat rendah (30-56\% dari RDA) untuk vitamin D, vitamin E, dan kalsium, rendah (61-69\%) untuk asupan zat besi, magnesium, seng, dan fosfor, cukup rendah (87-97\%) untuk vitamin $A$, vitamin $C$, tiamin, dan folat. ${ }^{15}$ Defisiensi vitamin B12 atau folat juga ditemukan pada remaja yang mengalami gangguan makan. ${ }^{16}$ Remaja yang mengalami gangguan makan memiliki kecenderungan membatasi asupan makan dan mengonsumsi jumlah kalori lebih rendah, terutama membatasi kalori yang berasal dari lemak, terutama sumber asupan hewani, sehingga meningkatkan risiko terjadinya anemia. ${ }^{17}$ Oleh karena itu, penelitian ini dilakukan untuk menganalisis hubungan gangguan makan, kualitas diet, dan status anemia pada Remaja Putri di Modelling school.

\section{METODE}

Subjek penelitian sebanyak 55 remaja putri yang berumur 12-19 tahun dipilih berdasarkan anggota beberapa sekolah model di Semarang yaitu Bayu Ramli Modelling school, Henry Modelling school, dan Lucette Management. Subjek diambil dengan cara consecutive sampling, yaitu semua subjek yang datang secara berurutan dan memenuhi kriteria pemilihan dimasukan kedalam penelitian sampai jumlah subjek terpenuhi. Kriteria inklusinya antara lain remaja putri yang terdaftar dalam sekolah model di Semarang, tidak sedang mengalami menstruasi pada saat pengambilan data, tidak memiliki riwayat penyakit terkait anemia, dan bersedia untuk diikutsertakan dalam penelitian dengan mengisi informed consent. Status gizi diukur berdasarkan indeks massa tubuh dan persen lemak tubuh. Indeks massa tubuh dikategorikan menjadi Underweight $\left(<18,5 \mathrm{~kg} / \mathrm{m}^{2}\right)$, Normal $(18,5-24,9$ $\left.\mathrm{kg} / \mathrm{m}^{2}\right)$, Overweight $\left(25-29,9 \mathrm{~kg} / \mathrm{m}^{2}\right)$, dan Obese $(\geq 30$ $\mathrm{kg} / \mathrm{m}^{2}$ ). Sedangkan hasil pengukuran persen lemak tubuh dikategorikan menjadi Underfat $(<15 \%)$, Normal (16-29\%), Overfat (30-34\%), dan Obese $(\geq 35 \%$ ). Berat badan diukur menggunakan timbangan digital dengan ketelitian $0,1 \mathrm{~kg}$ dan tinggi badan diukur menggunakan microtoise dengan ketelitian $0,1 \mathrm{~cm}$.

Variabel yang diteliti meliputi gangguan makan, kualitas diet, dan status anemia. Untuk variabel gangguan makan diukur menggunakan 
kuesioner Eating Disorder Diagnostic Scale (EDDS) dengan klasifikasi berdasarkan indikator Diagnostic and Statistical Manual of Mental Disorders, Fifth Edition (DSM-5).

Kualitas diet diukur dengan cara menilai konsumsi makanan menggunakan formulir food frequency questionnaire (FFQ), yang kemudian dihitung skor kualitas dietnya menggunakan formulir Diet Quality Index International (DQI-I). Skor untuk masing-masing kategori (variasi, kecukupan, moderasi, keseimbangan keseluruhan) dijumlahkan, kemudian skor dari seluruh kategori ditotal sehingga total DQI-I bisa bervariasi mulai dari 0 sampai 100 (0 adalah skor terendah dan 100 merupakan skor tertinggi). Kualitas diet dianggap rendah apabila total skor $\leq 60$ dan kualitas diet tinggi apabila skor $>60$. Status anemia pada remaja diukur dengan pemeriksaan kadar hemoglobin menggunakan metode Cyanmethemoglobin. Hasilnya dikategorikan menjadi anemia $(\mathrm{Hb}<12 \mathrm{~g} / \mathrm{dl})$ dan tidak anemia $(\mathrm{Hb}$ $\geq 12 \mathrm{~g} / \mathrm{dl})$.

Tabel 1. Karakteristik Subjek

\begin{tabular}{lccc}
\hline \multicolumn{1}{c}{ Karakteristik Subjek } & Rerata \pm SB & Minimum & Maksimum \\
\hline Usia (tahun) & $16,11 \pm 0,99$ & 12 & 19 \\
Berat Badan $(\mathrm{kg})$ & $51,99 \pm 12,83$ & 32,6 & 100,3 \\
Tinggi Badan $(\mathrm{cm})$ & $155,11 \pm 7,32$ & 140,0 & 171,0 \\
IMT $\left(\mathrm{kg} / \mathrm{m}^{2}\right)$ & $21,58 \pm 5,02$ & 16,0 & 41,2 \\
Persen lemak tubuh $(\%)$ & $25,91 \pm 10,40$ & 11,5 & 55,0 \\
\hline
\end{tabular}

Hasil penelitian disajikan dalam tabel distribusi frekuensi. Data numerik disajikan dalam bentuk rerata, standar deviasi/simpang baku, nilai maksimum, dan nilai minimum sedangkan data kategorik disajikan dalam bentuk persentase. Analisis univariat dilakukan untuk mengidentifikasi usia subjek, berat badan, tinggi badan, IMT, persen lemak tubuh, gangguan makan, skor kualitas diet, dan status anemia. Analisis bivariat dengan uji Chi Square untuk mengetahui hubungan gangguan makan dengan kualitas diet, hubungan gangguan makan dengan status anemia, dan hubungan kualitas diet dengan status anemia.

\section{HASIL}

\section{Karakteristik subjek}

Jumlah total subjek sebanyak 55 orang remaja putri memiliki karakteristik usia 12-19 tahun. Rerata IMT pada subjek $21,58 \pm 5,02 \mathrm{~kg} / \mathrm{m}^{2}$ dengan nilai terendah IMT $16 \mathrm{~kg} / \mathrm{m}^{2}$ dan nilai tertinggi 41,2 $\mathrm{kg} / \mathrm{m}^{2}$. Persen lemak tubuh pada remaja putri berkisar

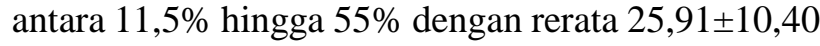
$\%$. Karakteristik subjek dapat dilihat pada Tabel 1.

Berdasarkan Tabel 2, pada gambaran status gizi menunjukkan masih ditemukan subjek dengan status gizi underweight (32,7\%), overweight $(12,7 \%)$ dan obesitas $(7,3 \%)$. Jika dilihat berdasarkan persen lemak tubuh, sebagian besar memiliki lemak tubuh dalam kategori normal $(67,3 \%)$, walaupun terdapat subjek yang berada di kategori obese (14,5\%). Pada penelitian ini, subjek yang mengalami gangguan makan sebanyak 29 subjek $(52,7 \%)$. Kualitas diet cenderung rendah pada remaja putri dengan ditemukan lebih banyak yang memiliki kualitas diet rendah $(63,6 \%)$. Anemia terjadi pada sebanyak 25 orang remaja putri $(45,5 \%)$.
Tabel 2. Gambaran Status Gizi, Gangguan Makan, Kualitas Diet, Status Anemia

\begin{tabular}{lrr}
\hline \multicolumn{1}{c}{ Kategori } & n & \% \\
\hline Status Gizi (IMT) & & \\
Underweight & 18 & 32,7 \\
Normal & 26 & 47,3 \\
Overweight & 7 & 12,7 \\
Obese & 4 & 7,3 \\
Status Gizi (Persen lemak tubuh) & & \\
$\quad$ Underfat & 5 & 9,1 \\
Normal & 37 & 67,3 \\
Overfat & 5 & 9,1 \\
Obese & 8 & 14,5 \\
Gangguan Makan & & \\
$\quad$ Gangguan makan & 29 & 52,7 \\
Tidak mengalami gangguan & 26 & 47,3 \\
Kualitas Diet & & \\
$\quad$ Rendah & 35 & 63,6 \\
$\quad$ Tinggi & 20 & 36,4 \\
Status Anemia & & \\
$\quad$ Anemia & 25 & 45,5 \\
Tidak Anemia & 30 & 54,5 \\
\hline
\end{tabular}

Hasil perhitungan asupan serat, zat besi, dan kalsium menunjukkan bahwa sebanyak subjek $(69,1 \%)$ kurang mencukupi kebutuhan zat besi per hari yaitu $26 \mathrm{mg}$, subjek $(56,4 \%)$ seratnya kurang dari kebutuhan yaitu 20-30 gram per hari, dan sebanyak subjek $(54,5 \%)$ kurang memenuhi kebutuhan kalsium berdasarkan angka kecukupan gizi yaitu $1200 \mathrm{mg}$ per hari. Hal ini didukung dengan subjek $(72,7 \%)$ kurang mengonsumsi 3-5 porsi sayur per hari dan subjek (50,9\%) kurang mengonsumsi $2-3$ porsi buah per hari. Sedangkan untuk pemenuhan konsumsi total lemak, subjek $(85,5 \%)$ mengonsumsi lebih dari $30 \%$ lemak dari total energi dan subjek $(83,6 \%)$ mengonsumsi lemak jenuh lebih dari $10 \%$ dari total energi per hari. 

Tabel 3. Gambaran Kategori Asupan Makan Subjek

\begin{tabular}{|c|c|c|c|}
\hline Kategori asupan makan & & $\mathbf{n}$ & $\%$ \\
\hline Serat & Baik $(\geq 20-30)$ & 6 & 10,9 \\
\hline \multirow[t]{2}{*}{ (g/hari) } & Cukup $(<20-10)$ & 18 & 32,7 \\
\hline & Kurang $(<10)$ & 31 & 56,4 \\
\hline Protein & Baik $(\geq 15)$ & 26 & 47,3 \\
\hline (\% energi/hari) & Cukup $(<15-7,5)$ & 29 & 52,7 \\
\hline Zat besi & Baik $(\geq 100)$ & 7 & 12,7 \\
\hline \multirow[t]{2}{*}{ (\% AKG mg/hari) } & Cukup $(<100-50)$ & 10 & 18,2 \\
\hline & Kurang $(<50)$ & 38 & 69,1 \\
\hline Kalsium & Baik $(\geq 100)$ & 7 & 12,7 \\
\hline \multirow[t]{2}{*}{ (\% AKG mg/hari) } & Cukup $(<100-50)$ & 18 & 32,7 \\
\hline & Kurang $(<50)$ & 30 & 54,5 \\
\hline Vitamin $\mathrm{C}$ & Baik $(\geq 100)$ & 24 & 43,6 \\
\hline \multirow[t]{2}{*}{ (\% AKG mg/hari) } & Cukup $(<100-50)$ & 7 & 12,7 \\
\hline & Kurang $(<50)$ & 24 & 43,6 \\
\hline Total lemak & Baik $(\leq 30)$ & 8 & 14,5 \\
\hline (\% total energi/hari) & Lebih $(>30)$ & 47 & 85,5 \\
\hline Lemak jenuh & Baik $(\leq 10)$ & 9 & 16,4 \\
\hline (\% total energi/hari) & Lebih $(>10)$ & 46 & 83,6 \\
\hline Kolesterol & Baik $(\leq 300)$ & 28 & 50,9 \\
\hline (mg/hari) & Lebih $(>300)$ & 27 & 49,1 \\
\hline Natrium & Baik $(\leq 2400)$ & 43 & 78,2 \\
\hline (mg/hari) & Lebih $(>2400)$ & 12 & 21,8 \\
\hline Makanan rendah gizi & Baik $(\leq 10)$ & 3 & 5,5 \\
\hline (\%total energi/hari) & Lebih $(>10)$ & 52 & 94,5 \\
\hline Kelompok sayuran & Baik $(\geq 3-5)$ & 5 & 9,1 \\
\hline \multirow[t]{2}{*}{ (porsi/hari) } & Cukup $(<3-1,5)$ & 10 & 18,2 \\
\hline & Kurang $(<1,5)$ & 40 & 72,7 \\
\hline Kelompok buah & Baik $(\geq 2-3)$ & 17 & 30,9 \\
\hline \multirow[t]{2}{*}{ (porsi/hari) } & Cukup $(<2-1)$ & 10 & 18,2 \\
\hline & Kurang $(<1)$ & 28 & 50,9 \\
\hline Makanan pokok & Baik $(\geq 3-8)$ & 42 & 76,4 \\
\hline (porsi/hari) & Cukup $(<3-1,5)$ & 13 & 23,6 \\
\hline
\end{tabular}

Kualitas diet terdiri dari empat kategori, yaitu variasi, kecukupan, moderasi, dan keseimbangan keseluruhan. Data kualitas diet menunjukkan skor kualitas diet subjek berkisar 37-74 dengan rerata 56,38 $\pm 8,997$ yang berarti kualitas diet pada subjek cenderung rendah. Rendahnya skor DQII menunjukkan bahwa subjek memiliki kebiasaan mengkonsumsi makanan yang tidak sesuai rekomendasi diet, melebihi atau kurang dari rekomendasi yang dianjurkan. Pada kategori variasi menunjukkan jumlah kelompok makanan dan jenis sumber protein yang dikonsumsi oleh subjek. Rerata skor variasi tidak menunjukkan rentang yang jauh.

Kategori kecukupan terdiri dari komponen kelompok sayuran, buah, makanan pokok, serat, protein, besi, kalsium, dan vitamin C. Kategori ini mengevaluasi unsur-unsur asupan makanan yang seharusnya tersedia dalam jumlah yang cukup. Hasil temuan menunjukkan rerata konsumsi sayuran $1,08 \pm 1,09$ porsi per hari dan buah $1,9 \pm 3,01$ porsi per hari. Asupan serat dengan rerata 11,7 $\pm 10,7$ gram/hari juga masih kurang jadi kebutuhan gram serat per hari. Zat besi juga memiliki rerata $13,1 \pm 10,5 \mathrm{mg}$ yang menunjukkan kurang asupan zat besi pada subjek.
Asupan vitamin $\mathrm{C}$ menunjukkan rentang yang cukup jauh pada rerata $91,7 \pm 111,7 \mathrm{mg}$ yang menunjukkan perbedaan asupan yang cukup besar pada subjek.

Komponen moderasi terdiri dari kecukupan pemenuhan lemak yang merupakan sumber makanan dengan nilai densitas energi paling tinggi yaitu 9 $\mathrm{kkal} / \mathrm{g}$. Kategori moderasi mengevaluasi asupan makanan dan zat gizi yang berhubungan dengan penyakit kronis dan perlu dibatasi yang terdiri dari total lemak, lemak jenuh, kolestrol, natrium, dan makanan rendah zat gizi. Total lemak yang dikonsumsi subjek memiliki rerata $76,9 \pm 53,5$ gram/hari dan asupan lemak jenuh dengan rerata $33,6 \pm 23,4$ gram/hari, sedangkan kolesterol memiliki rerata asupan $335,6 \pm 201,7 \mathrm{mg}$ dengan nilai maksimum 959,6 mg yang menunjukkan adanya asupan kolesterol berlebih. Asupan natrium pada subjek memiliki rerata $1620,4 \pm 1351,3 \mathrm{mg}$ dengan rentang yang cukup besar dan nilai maksimum asupan adalah 6979,2 mg yang berarti adanya kelebihan asupan natrium.

Keseimbangan keseluruhan merupakan kategori terakhir yang menganalisis keseimbangan keseluruhan diet dalam hal proporsionalitas antara 
sumber-sumber energi dan komposisi asam lemak. Kategori ini terdiri dari rasio makronutrien (karbohidrat : protein : lemak) yang memiliki rerata skor 1,7 $\pm 2,4$ dan rasio asam lemak (PUFA : MUFA : SFA) yang memiliki rerata skor $0,4 \pm 1,07$.

Tabel 4. Data Kualitas Diet Subjek

\begin{tabular}{lrrr}
\hline \multicolumn{1}{c}{ Data Kualitas Diet } & Rerata \pm SB & Minimum & Maksimum \\
\hline Kualitas diet (skor) & $56,4 \pm 8,9$ & 37 & 74 \\
Variasi (skor) & $19,5 \pm 1,8$ & 10 & 20 \\
Semua kelompok makanan & $14,6 \pm 1,3$ & 9,0 & 15,0 \\
(kelompok/hari) & & & \\
Sumber protein (jenis/hari) & $4,9 \pm 0,6$ & 1,0 & 5,0 \\
Kecukupan (skor) & $21,7 \pm 7,2$ & 12 & 38 \\
Kelompok sayuran (porsi/hari) & $1,08 \pm 1,09$ & 0,0 & 5,1 \\
Kelompok buah (porsi/hari) & $1,9 \pm 3,01$ & 0,0 & 15,3 \\
Kelompok makan pokok (porsi/hari) & $5,04 \pm 2,4$ & 0,6 & \\
Asupan serat (g/hari) & & & 71,6 \\
Protein (g/hari) & $11,7 \pm 10,7$ & 1,9 & 260,6 \\
Zat besi (mg/hari) & $80,6 \pm 53,09$ & 48,0 \\
Kalsium (mg/hari) & $13,1 \pm 10,5$ & 14,7 & 3309,0 \\
Vitamin C (mg/hari) & $698,3 \pm 584,9$ & 2,4 & 672,9 \\
& $91,7 \pm 111,7$ & 68,1 & 30 \\
Moderasi (skor) & $13,09 \pm 7,6$ & 0,0 & 237,4 \\
Total lemak (g/hari) & $76,9 \pm 53,5$ & 0 & 99,9 \\
Lemak jenuh (g/hari) & $33,6 \pm 23,4$ & 4,6 & 959,6 \\
Kolesterol (mg/hari) & $335,6 \pm 201,7$ & 1,0 & 6979,2 \\
Natrium (mg/hari) & $1620,4 \pm 1351,3$ & 29,3 & 103,0 \\
Makanan rendah zat gizi (\% total & $20,02 \pm 15,7$ & 145,4 & 8 \\
energi/hari) & & 0,8 & 673,7 \\
Keseimbangan keseluruhan (skor) & $2,1 \pm 2,5$ & & 99,9 \\
Karbohidrat (g/hari) & $277,7 \pm 131,3$ & 0 & 52,6 \\
Asam lemak jenuh/SFA (g/hari) & $33,6 \pm 23,4$ & 75,0 & 83,9 \\
PUFA (g/hari) & $14,2 \pm 10,8$ & 1,0 & 6 \\
MUFA (g/hari) & $23,5 \pm 17,6$ & 1,5 & 4 \\
Rasio makronutrien (skor) & $1,7 \pm 2,4$ & 1,4 & 5234,5 \\
Rasio asam lemak (skor) & $0,4 \pm 1,07$ & 0 & \\
Total energi (kkal) & $2125,5 \pm 1093,3$ & 0 & \\
\hline & & 448,7 & \\
& & & \\
& & & \\
\end{tabular}

Tabel 5. Hubungan Gangguan Makan dengan Status Anemia

\begin{tabular}{|c|c|c|c|c|}
\hline \multirow{2}{*}{ Gangguan Makan } & \multicolumn{2}{|c|}{ Status Anemia } & \multirow{2}{*}{$\begin{array}{l}\text { Total } \\
\text { n }(\%) \\
\end{array}$} & \multirow{2}{*}{$p$} \\
\hline & $\begin{array}{c}\text { Anemia } \\
\text { n (\%) }\end{array}$ & $\begin{array}{c}\text { Tidak anemia } \\
\text { n (\%) }\end{array}$ & & \\
\hline Gangguan Makan & $12(41,4 \%)$ & $17(58,6 \%)$ & $29(100,0 \%)$ & 0,243 \\
\hline Tidak Gangguan Makan & $13(50,0 \%)$ & $13(50,0 \%)$ & $26(100,0 \%)$ & \\
\hline
\end{tabular}

Tabel 6. Hubungan Kualitas Diet dengan Status Anemia

\begin{tabular}{|c|c|c|c|c|}
\hline \multirow[b]{2}{*}{ Kualitas Diet } & \multicolumn{2}{|c|}{ Status Anemia } & \multirow[b]{2}{*}{$\begin{array}{l}\text { Total } \\
\text { n }(\%)\end{array}$} & \multirow[b]{2}{*}{$p$} \\
\hline & $\begin{array}{c}\text { Anemia } \\
\text { n (\%) }\end{array}$ & $\begin{array}{c}\text { Tidak anemia } \\
\text { n }(\%)\end{array}$ & & \\
\hline Rendah & $16(45,7 \%)$ & $19(54,3 \%)$ & $35(100,0 \%)$ & 0,959 \\
\hline Tinggi & $9(45,0 \%)$ & $11(55,0 \%)$ & $20(100,0 \%)$ & \\
\hline
\end{tabular}

Tabel 7. Hubungan gangguan makan dengan kualitas diet

\begin{tabular}{lcccc}
\hline \multirow{2}{*}{ Gangguan Makan } & \multicolumn{2}{c}{ Kualitas Diet } & $\begin{array}{c}\text { Total } \\
\mathbf{n}(\boldsymbol{\%})\end{array}$ & $\boldsymbol{p}$ \\
\cline { 2 - 4 } & $\begin{array}{c}\text { Rendah } \\
\text { n(\%) }\end{array}$ & $\begin{array}{c}\text { Tinggi } \\
\mathbf{n}(\boldsymbol{\%})\end{array}$ & \\
\hline Gangguan Makan & $19(65,5 \%)$ & $10(34,5 \%)$ & $29(100,0 \%)$ & 0,866 \\
Tidak Gangguan Makan & $16(61,5 \%)$ & $10(38,5 \%)$ & $26(100,0 \%)$ & \\
\hline
\end{tabular}




\section{Hubungan Gangguan Makan dan Kualitas Diet dengan Status Anemia}

Berdasarkan temuan yang diperolehpada tabel 5, sebanyak 12 subjek $(41,4 \%)$ yang anemia mengalami gangguan makan, namun juga lebih banyak ditemukan gangguan makan pada subjek $(58,6 \%)$ yang tidak mengalami anemia $(p=0,243)$.

Tabel 6 menunjukkan sebanyak 16 subjek $(45,7 \%)$ yang mengalami anemia memiliki kualitas diet yang rendah dan lebih banyak ditemukan jumlah kualitas diet rendah pada subjek $(54,3 \%)$ yang tidak anemia yaitu sebanyak 19 orang $(p=0,959)$.

Tabel 7 menunjukkan hasil bahwa kualitas diet rendah ditemukan lebih banyak pada kelompok yang mengalami gangguan makan $(65,5 \%)$ yaitu sebanyak 19 subjek dan juga banyak ditemukan subjek $(61,5 \%)$ yang tidak mengalami gangguan makan $(p=0,866)$.

Hasil analisis uji Chi Square diperoleh nilai $p>0,05$ yang menunjukkan bahwa tidak ada hubungan bermakna antara gangguan makan dan kualitas diet dengan status anemia pada remaja putri.

\section{PEMBAHASAN}

Masalah gizi utama pada remaja adalah defisiensi mikronutrien, khususnya anemia defisiensi zat besi, serta gizi kurang, gizi lebih sampai obesitas dengan ko-morbiditasnya yang keduanya seringkali berkaitan dengan perilaku makan salah dan gaya hidup. ${ }^{18}$ Prevalensi masalah gizi antara lain underweight, overweight, dan obesitas yang ditemukan pada penelitian ini berbeda dengan penelitian pada status gizi model yang menunjukkan angka prevalensi underweight tinggi dan tidak ditemukan prevalensi gizi lebih maupun obesitas. ${ }^{9}$ Status gizi berdasarkan persen lemak tubuh pada penelitian ini juga menunjukkan adanya prevalensi underfat, overfat, dan obese berbeda dengan penelitian di Semarang yang tidak menemukan prevalensi overfat dan obesitas pada model remaja putri. ${ }^{14}$

Penelitian ini menemukan remaja putri sebanyak 29 subjek mengalami gangguan makan dengan rincian kategori 11 subjek (20\%) mengalami bulimia nervosa, 9 subjek (16,4\%) mengalami binge eating disorder, dan 9 subjek $(16,4 \%)$ termasuk dalam kategori gangguan makan lainnya yang disebut Other Specified Feeding or Eating Disorder (OSFED). Temuan ini sesuai dengan penelitian di Modelling Agency Semarang yang juga menemukan prevalensi remaja putri $(67,8 \%)$ mengalami gangguan makan. ${ }^{14}$ Tingginya gangguan makan pada penelitian ini disebabkan dengan sebagian besar subjek yang merasa gemuk dan takut mengalami kenaikan berat badan, serupa dengan penelitian yang menunjukkan banyaknya remaja putri $(46,2 \%)$ yang merasa gemuk menjadi awal terjadinya gangguan makan. ${ }^{19}$ Pola makan dan perilaku remaja dipengaruhi oleh banyak faktor, salah satunya adalah citra tubuh dan gangguan makan pada remaja putri berkorelasi dengan citra tubuh yang negatif. Remaja putri menerapkan perilaku tidak tepat dalam mencapai bentuk tubuh ideal seperti melakukan kompensasi memuntahkan makanan, menggunakan obat diet, sengaja mengurangi porsi makan, atau olahraga secara berlebihan..$^{20}$ Citra tubuh negatif juga ditemukan pada penelitian terhadap model remaja putri di Surabaya yang menunjukkan kecenderungan remaja putri melakukan diet ketat seperti fads diet untuk mengurangi jumlah kalori dan asupan zat gizi tertentu. ${ }^{21}$

Kualitas diet rendah pada penelitian ini lebih banyak dibandingkan dengan remaja yang memiliki kualitas diet tinggi. Seperti halnya dengan penelitian kualitas diet di Semarang yang menemukan kualitas diet rendah seluruhnya terjadi pada remaja putri. ${ }^{22}$ Kualitas diet yang rendah pada remaja putri menunjukkan bahwa kurangnya asupan makanan yang berdensitas energi rendah seperti sayur dan buah, serta menunjukkan konsumsi makanan secara keseluruhan tidak sesuai dengan rekomendasi gizi seimbang. ${ }^{20}$ Remaja cenderung memilih jenis makanan tinggi gula, natrium, dan lemak serta kurang vitamin dan mineral, ditunjukkan pada penelitian ini remaja putri dengan asupan lemak berlebih dan rerata asupan natrium yang cukup tinggi, serta kurangnya asupan zat gizi seperti zat besi, kalsium, dan serat. ${ }^{6}$

Secara lebih rinci, asupan serat, zat besi, dan kalsium pada subjek sebagian besar dikategorikan kurang memenuhi kebutuhan berdasarkan angka kecukupan gizi per hari, serta subjek memiliki asupan lemak berlebih. Selain itu, terdapat pula subjek dengan asupan natrium yang tinggi yaitu 6979,2 $\mathrm{mg} /$ hari (asupan rekomendasi $1500 \mathrm{mg} / \mathrm{hari}$ ). Hal ini terjadi karena remaja yang lebih banyak mengonsumsi makanan rendah gizi, makanan olahan tinggi natrium, dan rendah asupan serat. Asupan serat yang rendah disebabkan rendahnya konsumsi kelompok makanan yang memiliki serat tinggi, seperti sayuran dan buah-buahan. Proporsi konsumsi buah/sayur yang kurang juga ditunjukkan pada data riskesdas terbaru tahun 2018, rata-rata prevalensi konsumsi sayur/buah di Indonesia $(95,5 \%)$ yang menunjukkan masih tingginya angka konsumsi sayur dan buah yang kurang dari kebutuhan. ${ }^{23}$

Berdasarkan pemenuhan zat gizi subjek penelitian ini, beberapa komponen pada kategori kecukupan dan moderasi yang menunjukkan rendahnya kualitas diet. Kualitas diet yang rendah disebabkan oleh berlebihnya zat gizi yang ada pada kategori moderasi dan kurangnya beberapa zat gizi di kategori kecukupan. Hal ini serupa dengan penelitian 
kualitas diet pada remaja yang menunjukkan rendahnya kualitas diet dilihat berdasarkan kategori kecukupan dan moderasi. ${ }^{25}$ Kategori moderasi berperan dalam rendahnya kualitas diet pada komponen lemak jenuh, total lemak, dan tingginya asupan makanan rendah gizi. Rendahnya asupan zat gizi yang ada di kategori kecukupan juga dapat menjadi faktor berkontribusi terjadinya anemia yang ditunjukkan pada tingkat kecukupan zat besi. Pada penelitian ini ditemukan subjek sebanyak 25 orang memiliki kadar $\mathrm{Hb}$ kurang dari $12 \mathrm{~g} / \mathrm{dl}$ yang termasuk kelompok yang mengalami anemia. Temuan ini serupa dengan penelitian di Bengkulu yang menemukan prevalensi anemia (43\%) pada remaja putri. $^{24}$

\section{Hubungan gangguan makan dan kualitas diet dengan status anemia}

Hasil uji statistik menunjukkan tidak terdapat hubungan antara gangguan makan, kualitas diet, dengan status anemia. Hal ini dikarenakan proporsi gangguan makan dan kualitas diet yang rendah juga banyak ditemukan pada remaja putri baik yang mengalami anemia maupun yang memiliki kadar $\mathrm{Hb}$ normal. Hasil penelitian ini serupa dengan temuan di Bengkulu yang menunjukkan tidak terdapat hubungan antara pola makan dengan kejadian anemia. ${ }^{24}$

Anemia pada remaja putri terjadi karena beberapa faktor antara lain yaitu pendarahan karena haid, penyakit infeksi, penyakit kronik, aktifitas fisik, dan kurangnya asupan zat gizi tertentu. ${ }^{26}$ Perilaku makan buruk yang ditandai dengan adanya gangguan makan dan kualitas diet yang rendah, dapat meningkatkan risiko terjadinya anemia pada remaja putri. Hal ini disebabkan karena inadekuat asupan zat besi yang berasal dari makanan. Remaja putri lebih sering melakukan pengurangan makan sehingga kebutuhan zat besi tidak terpenuhi. ${ }^{20}$ Asupan zat besi yang rendah tidak langsung menimbulkan gangguan seperti turunnya kadar hemoglobin secara cepat. Pada tahap pertama terjadi deplesi zat besi yang mengakibatkan berkurangnya cadangan zat besi yang tersimpan pada hati, sumsum tulang dan otot dalam bentuk ferritin. Pada tahap kedua terjadi deplesi zat besi yang lebih besar. Asupan yang cukup atau suplementasi dapat mencegah terjadinya gangguan dan penyakit pada tahap ini. Tahap ketiga ditandai dengan rendahnya cadangan zat besi. Pada tahap ini belum dijumpai anemia dengan indikator kadar hemoglobin yang rendah. Tahap keempat ditandai dengan kadar hemoglobin yang rendah sebagai salah satu indikator adanya anemia. ${ }^{27}$

\section{SIMPULAN}

Masalah status gizi pada remaja putri yang ditemukan antara lain underweight, overweight, dan obesitas. Sebagian besar remaja putri mengalami gangguan makan (52,7\%), kualitas diet rendah $(63,6 \%)$, dan tingginya prevalensi anemia $(45,5 \%)$ pada remaja putri di sekolah model Semarang. Gangguan makan dan kualitas diet rendah ditemukan baik pada remaja putri yang mengalami anemia maupun yang kadar $\mathrm{Hb}$ normal. Kualitas diet rendah ditemukan lebih banyak pada kelompok yang mengalami gangguan makan, namun pada penelitian ini tidak terdapat hubungan bermakna antara gangguan makan dan kualitas diet dengan status anemia pada remaja putri di modelling school.

Remaja putri perlu meningkatkan asupan makanan dengan densitas energi rendah seperti sayur dan buah sesuai kebutuhan untuk meningkatkan kualitas diet. Upaya pencegahan anemia dapat dilakukan dengan memperkaya asupan zat besi, mengonsumsi tablet tambah darah sebelum dan selama menstruasi, serta meningkatkan pengetahuan terkait anemia remaja putri melalui edukasi gizi. Selain itu, konseling gizi mengenai citra tubuh positif perlu diberikan bagi remaja putri untuk mencegah terjadinya gangguan makan. Pemantauan status gizi secara berkala juga penting untuk menjaga status gizi tetap normal.

\section{DAFTAR PUSTAKA}

1. WHO. Haemoglobin concentrations for the diagnosis of anaemia and assessment of severity. In 2011. hal. 1-6.

2. WHO. The global prevalence of anaemia in 2011. Geneva, Switzerland: World Health Organization; 2015.

3. Kementerian Kesehatan RI. Riset kesehatan dasar. 2013.

4. Mariana W, Khafidhoh N. Hubungan status gizi dengan kejadian anemia pada remaja putri di SMK Swadaya wilayah kerja Puskesmas Karangdoro Kota Semarang tahun 2013. Jurnal Kebidanan. 2013;2(4):35-42.

5. Utami BN, Surjani S, Mardiyaningsih E. Hubungan pola makan dan pola menstruasi dengan kejadian anemia remaja putri. Jurnal Keperawatan Soedirman. 2015;10(2):67-75.

6. Brown JE. Nutrition through the life cycle. 4 ed. United States: Wadsworth Cengage Learning; 2011.

7. Pakar Gizi Indonesia. Ilmu gizi: teori \& aplikasi. Hardinsyah, Supariasa IDN, editor. EGC; 2016.

8. Preti A, Usai A, Miotto P, Rita D, Masala C. Eating disorders among professional fashion models. Psychiatry Research. 2008;159:86-94.

9. Haq AB, Murbawani EA. Status gizi, asupan makan pada remaja putri yang berprofesi sebagai model. Journal of Nutrition College. 2014;3(4):489-94. 
10. Swami V, Szmigielska E. Body image concerns in professional fashion models: Are they really an at-risk group? Psychiatry Research. 2013;207(1-2):113-7.

11. Balcı YI, Karabulut A, Gürses D, Çövüt İE. Prevalence and risk factors of anemia among adolescents in Denizli, Turkey. Iranian Journal of Pediatrics. 2012;22(1):77-81.

12. Tesfaye M, Yemane T, Adisu W, Asres Y, Gedefaw L. Anemia and iron deficiency among school adolescents: burden, severity, and determinant factors in southwest Ethiopia. Adolescent Health, Medicine and Therapeutics. 2015;6:189-96.

13. Shill KB, Karmakar P, Kibria G, Das A, Rahman MA, Hossain MS, et al. Prevalence of iron-deficiency anaemia among university students in Noakhali Region, Bangladesh. Journal of Health, Population and Nutrition. 2014;32(1):103-10.

14. Syarafina A, Probosari E. Hubungan eating disorder dengan status gizi pada remaja putri di modeling agency Semarang. Journal of Nutrition College. 2014;3(2):48-53.

15. Zimmerman J, Santiago A, Feinstein R, Fisher M. Do adolescents with eating disorders meet recommended dietary allowances, despite their descreased calorie intakes? Journal of the Academy of Nutrition and Dietetics. 2016;116(9):A77.

16. Misra M, Aggarwal A, Miller KK, Almazan C, Worley M, Soyka LA, et al. Effects of anorexia nervosa on clinical, hematologic, biochemical, and bone density parameters in communitydwelling adolescent girls Madhusmita. Pediatrics. 2004;114(6):1574-83.

17. Walsh BT. The importance of eating behavior in eating disorders. Physiol Behav. 2012;104(4):525-9.

18. Satgas Remaja IDAI. Nutrisi pada remaja [Internet]. 2013 [dikutip 10 Mei 2019]. Tersedia pada: http://www.idai.or.id/artikel/seputarkesehatan-anak/nutrisi-pada-remaja

19. Yuliana BN, Dieny FF. Ketidakpuasan terhadap citra tubuh dan kejadian female athlete triad (FAT) pada remaja putri. Journal of Nutrition College. 2013;2(4):705-12.

20. Dieny FF. Permasalahan gizi pada remaja putri. Yogyakarta: Graha Ilmu; 2014.

21. Nurjannah I, Muniroh L. Body image, tingkat kecukupan zat gizi, dan FAD diets pada model remaja putri di Surabaya. MGI. 2019;14(1):95105.

22. Dewi UP, Dieny FF. Hubungan antara densitas energi dan kualitas diet dengan indeks massa tubuh (IMT) pada remaja. Journal of Nutrition College. 2013;2(4):447-57.

23. Kementerian Kesehatan RI. Riset kesehatan dasar. 2018.

24. Suryani D, Hafiani R, Junita R. Analisis pola makan dan anemia gizi besi pada remaja putri kota Bengkulu. Jurnal Kesehatan Masyarakat Andalas. 2015;10(1):11-8.

25. Retnaningrum G, Dieny FF. Kualitas diet dan aktivitas fisik pada remaja obesitas dan non obesitas. Journal of Nutrition College. 2015;4(2):469-79.

26. Permaesih D, Herman S. Faktor-Faktor Yang Mempengaruhi Anemia Pada Remaja. Buletin Penelitian Kesehatan. 2005;33:162-71.

27. Stopler T. Medical nutrition theraphy for anemia. krause's food and nutrition theraphy. 11th ed. Philadelphia: Saunders; 2004. 